\title{
THE INFLUENCE OF BIOMASS QUALITY ON THE STABILITY AND SUSTAINABILITY OF DISTRICT HEATING SYSTEMS OF LOW-ACCUMULATION OBJECTS
}

\author{
Ante Čikić, Vinko Višnjić, Marko Dunđer
}

Original scientific paper

Research was conducted during the incineration of six different biomass groups, whereat each group was observed for three cases of average initial moisture level for the purpose of quantifying the values of impact parameters and contribution to the correlation between biomass quality and the efficiency of a thermal power system. A hot water plant with the power to heat ratio amounting to $Q=600 \mathrm{~kW}$ was used, which included a district heating system of a low-accumulation object with a low thermophysical constant and a low time constant. Research was conducted in 18 equal cycles at low outside air temperatures and a maximum need for useful thermal energy. Quantified values showed the consumption of all groups of all average moisture levels of biomass. By analysing the examined temperature of a heating medium and flue gases during the combustion of each biomass group, a direct influence of its quality and average moisture on the sustainability and stability of the district heating system was shown. The most favourable biomass was proposed. Direct application of research results contributes to correct determination of the type, composition and average moisture of biomass, as well as a higher efficiency of the whole thermal power system.

Keywords: biomass quality; district heating system; flue gases; heating medium; heating stability and sustainability; low-accumulation object; thermal power plant

Utjecaj kakvoće biomase na stabilnost i održivost toplifikacijskih sustava niskoakumulativnih objekata

Izvorni znanstveni članak

Provedena su istraživanja pri spaljivanju šest različitih skupina biomase, svaka skupina za tri slučaja prosječne početne vlage u cilju kvantificiranja vrijednosti utjecajnih parametara i doprinosa povezanosti kakvoće biomase s učinkovitosti termoenergetskog sustava. Korišteno je toplovodno postrojenje toplinske snage $Q=600 \mathrm{~kW}$ sa toplifikacijskim sustavom niskoakumulativnog objekta s malom termofizikalnom karakteristikom i vremenskom konstantom.Istraživanja su provedena u osamnaest jednakih ciklusa pri niskim vanjskim temperaturama zraka i maksimalnoj potrebi korisne toplinske energije. Kvantificiranim vrijednostima utvrđena je potrošnja svih skupina i prosječne vlažnosti biomase. Analizom ispitivane temperature ogrjevnog medija i dimnih plinova pri izgaranju svake skupine biomase prikazan je izravan utjecaj njene kakvoće i prosječne vlage na održivost i stabilnost toplifikacijskog sustava. Predložena je najpovoljnija biomasa. Izravnom primjenom rezultata istraživanja doprinosi se pravilnom određivanju vrste, sastava i prosječne vlage biomase, te većoj učinkovitosti cjelovitog termoenergetskog sustava.

Ključne riječi: dimni plinovi; kakvoća biomase; niskoakumulativni objekt; ogrjevni medij; stabilnost i održivost grijanja; termoenergetsko postrojenje, toplifikacijski sustav

\section{Introduction}

Waste biomass accumulates during production at wood-processing plants and/or regular work in forests. It is globally used more or less as drive fuel in the production of thermal (boiler room, power plants) and/or electrical and thermal energy at cogeneration plants of various sizes and levels of power. It is frequent that the type, structure, composition and state of biomass as drive fuel is superficially estimated, which affects the efficiency and cost-effectiveness of thermal power system to a large extent. Due to the lack of exact research and precise indicators on the quality of indirectly used biomass, required amounts and its storage capacities are imprecisely determined. Due to variable biomass quality, there is stressed drive instability between the thermal source and thermal energy consumers with frequent oscillations, especially at low-accumulation objects that require a lot of time to heat up, but rapidly cool down [1, 2]. Unbalanced combustion, variable thermal load on the heat exchange surface of the boiler, presence of various non-combustible matters and deposits on the heat exchange surfaces, as well as slow achieving of work temperature of the heating medium are frequent occurrences during the incineration of chipped wood mass, which affect the efficiency and safety of a thermal power plant drive, as well as the sustainability and stability of the district heating system $[3,4,5,6,7]$.
For this reason research was carried out during the incineration of six different types, compositions and moisture levels of biomass that are frequently applicable in practice, for the purpose of quantifying the values and scientific contribution of the correlation of biomass quality and the efficiency of the thermal power system.

\section{Research object, material and method}

\subsection{Object and material}

For trial research a new hot water plant for the incineration of biomass, the power to heat ratio of which amounts to $Q=600 \mathrm{~kW}$ was designed and constructed for the purpose of heating a low-accumulation object greenhouse (10) for hydroponic growing of tomatoes. The plant for biomass incineration and conversion into thermal energy is shown in Fig. 1. It consists of a container, the volume of which amounts to $27 \mathrm{~m}^{3}$ (1) with an automatic dosage and supply system (2), automated pyrolytic chamber (3) and a low-pressure hot water boiler with the maximum hot water temperature work mode amounting to $90 / 70{ }^{\circ} \mathrm{C}$ (4). By means of a transport centrifugal ventilator (5), flue gases purified in a cyclone (6) are removed through a steel chimney (7) and dispersed into the atmosphere. A circulation pump (9) was used for maintaining a constant hot water flow $V_{\mathrm{w}}=25,6 \mathrm{~m}^{3} / \mathrm{h}$. A variable mixture of chipped biomass was used: beech, oak and hornbeam wood chips sized $20 \div 50 \mathrm{~mm}$, sawdust, other small wood waste, dry and green bark, side 
trimmings and wood residues $<50 \mathrm{~mm}$, as well as chipped thin wood logs and branches. Biomass is stored in a covered space directly next to the hot water plant.

Trial research was carried out in February 2014 at low external air temperatures when the consumption of electrical energy was at its peak. Research was conducted by incinerating various biomass mixtures separated in six groups, I-VI, each group for three average initial moisture scenarios, Tab. 1.
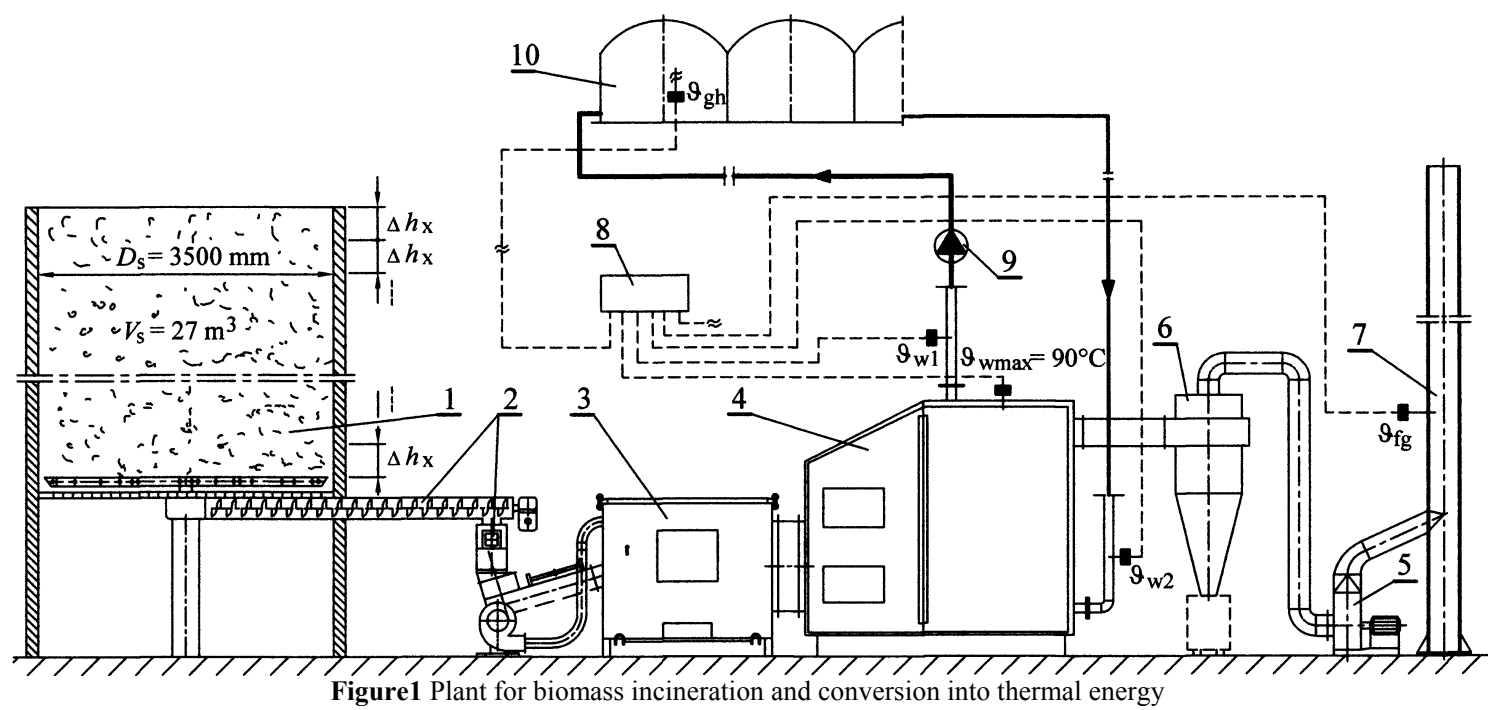

Table1 Biomass mixture (groups I to VI) and average initial moisture $u_{\text {av }}$ (1 to 3 )

\begin{tabular}{|c|c|c|c|c|}
\hline \multirow{2}{*}{ Group } & \multirow{2}{*}{ Biomass mixture } & \multicolumn{3}{|c|}{ Average initial moisture $u_{\mathrm{av}} / \%$} \\
\hline & & $u_{\mathrm{av} 1}$ & $u_{\mathrm{av} 2}$ & $u_{\mathrm{av} 3}$ \\
\hline I & $\begin{array}{l}\text { Beech and hornbeam wood chips sized } 20 \div 50 \mathrm{~mm} \text { (around } 55 \% \text { ) }+ \text { other small } \\
\text { combustible waste (around } 20 \% \text { ) + chipped dry and green bark, side trimmings, } \\
\text { wood residues, thin wood logs and branches (around } 25 \% \text { ) }\end{array}$ & $\approx 28$ & $\approx 42$ & $\geq 65$ \\
\hline II & $\begin{array}{l}\text { Beech and hornbeam wood chips sized } 20 \div 50 \mathrm{~mm} \text { in approximately equal } \\
\text { proportion }\end{array}$ & $\approx 26$ & $\approx 44$ & $\approx 62$ \\
\hline III & $\begin{array}{l}\text { Beech and oak wood chips sized } 20 \div 50 \mathrm{~mm} \text { in approximately equal proportion } \\
\text { (around } 50 \% \text { ) }+ \text { beech and oak sawdust (around } 50 \% \text { ) }\end{array}$ & $\approx 26$ & $\approx 41$ & $\approx 57$ \\
\hline IV & $\begin{array}{l}\text { Beech and oak wood chips sized } 20 \div 50 \mathrm{~mm} \text { in approximately equal proportion } \\
\text { (around } 30 \% \text { ) }+ \text { beech and oak sawdust (around } 70 \% \text { ) }\end{array}$ & $\approx 23$ & $\approx 45$ & $\approx 56$ \\
\hline $\mathrm{V}$ & Beech and oak sawdust in approximately equal proportion & $\approx 17$ & $\approx 30$ & $\approx 52$ \\
\hline VI & $\begin{array}{l}\text { Beech and oak wood chips sized } 20 \div 50 \mathrm{~mm} \text { in approximately equal proportion } \\
\text { (around } 70 \% \text { ) }+ \text { beech and oak sawdust (around } 30 \% \text { ) }\end{array}$ & $\approx 25$ & $\approx 40$ & $\approx 54$ \\
\hline
\end{tabular}

\subsection{Research method}

Biomass mixture samples for groups I to VI are shown in Fig. 2. For each group (I to VI) the average initial moisture of the biomass mixture was determined as the arithmetic mean of the measured moisture in five measuring points during the filling of the $V_{\mathrm{s}}$ container, before the start of the combustion process. Three combustion processes for each group were carried out, with the average biomass moisture being in the range between $17 \%$ and $\geq 65 \%$, whereat $u_{\text {av1 }}<u_{\text {av2 }}<u_{\text {av3 } 3}$. Moisture measurements were carried out by means of a digital hygrometer Higrotest 6500. Measurement accuracy depends on the wood type and temperature, so special switches on the instrument were used for selecting the dominant wood type for every single group and temperature range. A prismatic plastic container with thin walls and dimensions amounting to $V_{\mathrm{p}}=0,12 \times 0,12 \times$ $0,15 \mathrm{~m}^{3}$ was used for biomass mixture sampling for determining its mean mass $m_{\mathrm{bm}(\mathrm{I} \div \mathrm{VI}) x}$ with average moisture $u_{\mathrm{avx}}$ and average density $\rho_{\mathrm{bmo}(\mathrm{I} \div \mathrm{VI})}$ of absolutely dry biomass. By means of electronic scales of the accuracy class of $1 / 100$ gand the measurement area of $0 \div$ $1000 \mathrm{~g}$, the mass of each sample $m_{\mathrm{bm}(\mathrm{I} \div \mathrm{VI}) x}$ was measured in dispersed state. Biomass mixture density $\rho_{\mathrm{bm}(\mathrm{I} \div \mathrm{VI}) x}$ of the average moisture $u_{\mathrm{avx}}$ was determined using the following relation:

$\rho_{\mathrm{bm}(\mathrm{I} \div \mathrm{VI}) x}=\frac{m_{\mathrm{bm}(\mathrm{I} \div \mathrm{VI}) x}}{V_{\mathrm{p}}}, \mathrm{kg} / \mathrm{m}^{3}$.

The same amount of biomass was dried in an electric dryer until it was completely dry. Upon drying its mass $m_{\text {bmo(I } \div \mathrm{VI})}$ was measured. A container with the volume $V_{\mathrm{p}}$ was used for measuring the volume $V_{\mathrm{bmo}(\mathrm{I} \div \mathrm{VI})}$ and its density in absolutely dry state was calculated:

$\rho_{\mathrm{bmo}(\mathrm{I} \div \mathrm{VI})}=\frac{m_{\mathrm{bmo}(\mathrm{I} \div \mathrm{VI})}}{V_{\mathrm{bmo}(\mathrm{I} \div \mathrm{VI})}}, \mathrm{kg} / \mathrm{m}^{3}$.

Values of biomass mixture density in absolutely dry state for individual groups amounted to: $\rho_{\mathrm{bmo}, \mathrm{I}}=280$ $\mathrm{kg} / \mathrm{m}^{3}, \rho_{\text {bmo,II }}=310 \mathrm{~kg} / \mathrm{m}^{3}, \rho_{\text {bmo,III }}=300 \mathrm{~kg} / \mathrm{m}^{3}, \rho_{\text {bmo,IV }}=$ $290 \mathrm{~kg} / \mathrm{m}^{3}, \rho_{\mathrm{bmo}, \mathrm{V}}=280 \mathrm{~kg} / \mathrm{m}^{3}$ and $\rho_{\mathrm{bmo}, \mathrm{VI}}=340 \mathrm{~kg} / \mathrm{m}^{3}$. Density of an individual biomass mixture group (I do VI) 
for various moisture levels was determined by the following equation:

$$
\begin{aligned}
& \rho_{\mathrm{bm}(\mathrm{I} \div \mathrm{VI}) x}=\rho_{\mathrm{bmo}(\mathrm{I} \div \mathrm{VI})} \cdot\left(u_{\mathrm{av} x}+1\right), \mathrm{kg} / \mathrm{m}^{3} \\
& x=1,2,3 .
\end{aligned}
$$

The incineration of various biomass mixtures was carried out in 18 cycles under similar external microclimate conditions $\left(\vartheta_{\mathrm{e}} \cong-10{ }^{\circ} \mathrm{C}\right.$ to $-15{ }^{\circ} \mathrm{C}$ ) and the maximum load on the pyrolytic chamber and hot water boiler of the heat to power ratio amounting to $600 \mathrm{~kW}$. In all cycles of heating by using biomass, the internal air temperature in the zone of growing tomatoes $\vartheta_{\text {gh }}$ in a greenhouse was within the allowed technological limits, between the minimal $14{ }^{\circ} \mathrm{C}$ and the required $19{ }^{\circ} \mathrm{C}$. Each test cycle lasted for 18 hours. The container $V_{\mathrm{s}}$ of an individual group and average biomass moisture was either refilled or completely emptied. In some cycles, after the parameters had been measured, the drive state of the thermal power plant was prolonged within 18 hours until the container $V_{\mathrm{s}}$ of an individual group and average biomass moisture was completely emptied. After each cycle pyrolytic chamber, boiler furnace and the heat exchange surface at the side of hot combustion gases were cleaned. During each trial cycle of biomass combustion the following was measured:

- initial hot water temperature $\vartheta_{\mathrm{w} 1}$,

- reversed hot water temperature $\vartheta_{\mathrm{w} 2}$,

- internal air temperature in the zone of growing tomatoes $\vartheta_{\mathrm{gh}}$,

- flue gas temperature at the chimney inlet after purification $\vartheta_{\text {fg }}$.

Using an adapted measuring-regulation system (8) and software support, numerical values of measured parameters were registered each 15 minutes, and the cumulative average value for the interval of each hour as the arithmetic mean of the four measured values according to the equation:

$$
\vartheta(t)_{x}=\bar{x}=\frac{1}{N} \sum_{i=1}^{N} x_{i}, x_{i}=\vartheta_{i}, x_{i}=t_{i}, N=4
$$

Within a sequence of intervals of every 2 hours, in each incineration cycle, biomass consumption was determined according to the following relation:

$$
m_{\mathrm{bm}(\mathrm{I} \div \mathrm{VI}) x}=\rho_{\mathrm{bmo}(\mathrm{I} \div \mathrm{VI})} \cdot\left(u_{\mathrm{av} x}+1\right) \cdot \frac{D_{\mathrm{s}}^{2} \cdot \pi}{4} \cdot \Delta h_{x}, \mathrm{~kg} / 2 \mathrm{~h}
$$

The overall amount was determined by adding up biomass consumption in all measurement intervals in each incineration cycles for 18 hours according to the equations

$$
\begin{aligned}
& m_{\mathrm{bm}(\mathrm{I} \div \mathrm{VI}) \text { total }}=\sum_{i=1}^{N_{1}} m_{\mathrm{bm}(\mathrm{I} \div \mathrm{VI}) x}, \mathrm{~kg} \quad N_{1}=9, \\
& V_{\mathrm{bm}(\mathrm{I} \div \mathrm{VI}) x}=\frac{m_{\mathrm{bm}(\mathrm{I} \div \mathrm{VI}) \text { total }}}{v_{\mathrm{bm}(\mathrm{I} \div \mathrm{VI}) x}}, \mathrm{~m}^{3} .
\end{aligned}
$$

The maximum adjusted hot water temperature of the initial conduit from the boiler in each biomass incineration cycle amounted to $\vartheta_{\mathrm{w}, \max }=90^{\circ} \mathrm{C}$. By using the so called " $\lambda$ - probe", air overflow was automatically adjusted and dosed in each incineration cycle of individual groups and moisture levels of biomass.
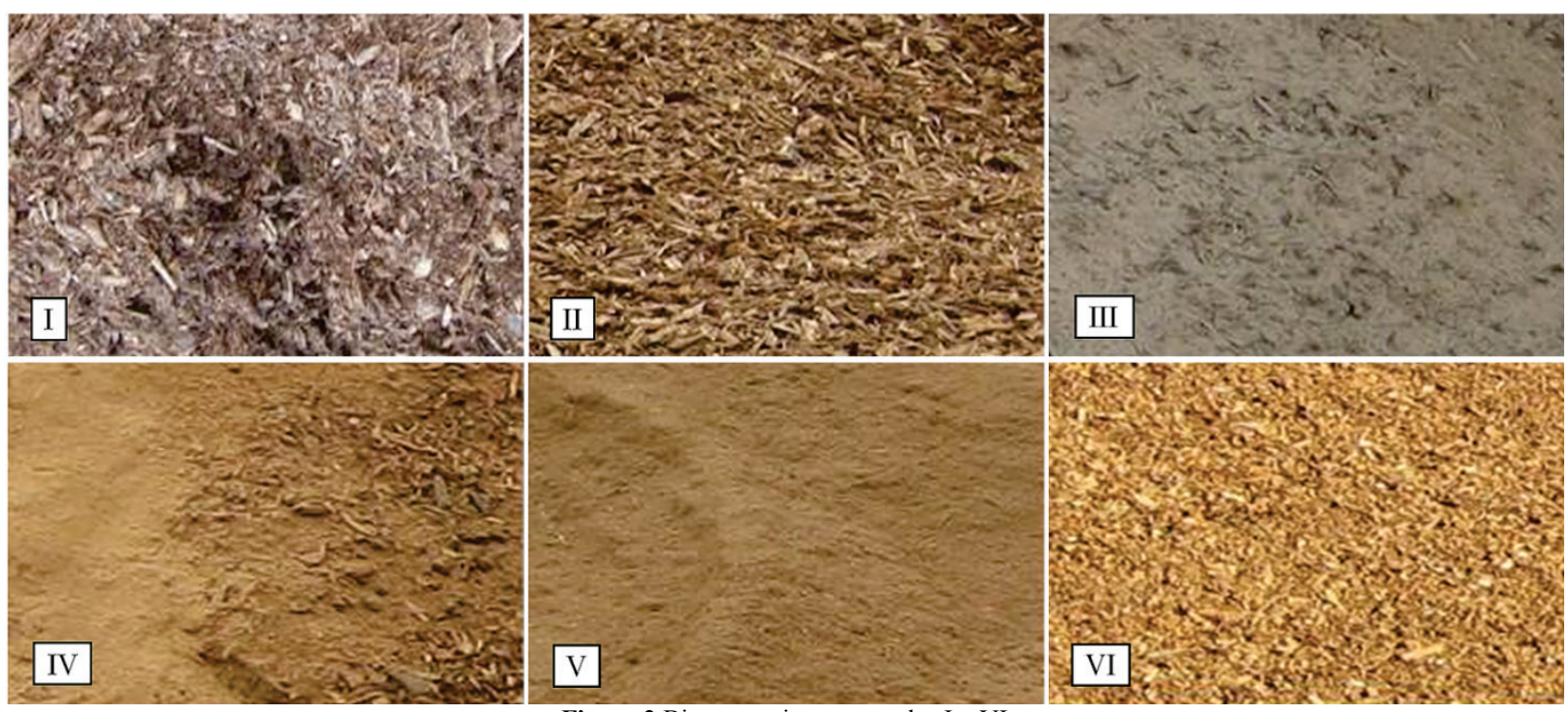

Figure 2 Biomass mixture samples I - VI

\section{Measurement results}

The measured values of hot water temperatures $\vartheta_{\mathrm{w} 1}$ during the combustion of biomass mixtures of groups I to VI, each for three different average moisture levels $\left(u_{\mathrm{av} 1}<u_{\mathrm{av} 2}<u_{\mathrm{av} 3}\right)$ and in equal time intervals amounting to
18 hours, are shown in diagrams in Figs. 3, 4 and 5. The difference between the initial and reversed water temperature $\left(\Delta \vartheta_{\mathrm{w}}=\vartheta_{\mathrm{w} 1}-\vartheta_{\mathrm{w} 2}\right)$ directly in front of the boiler (upon the heated area was supplied with heat) amounted to $15^{\circ} \mathrm{C}$ to $21^{\circ} \mathrm{C}$, i.e. averagely $18^{\circ} \mathrm{C}$. 


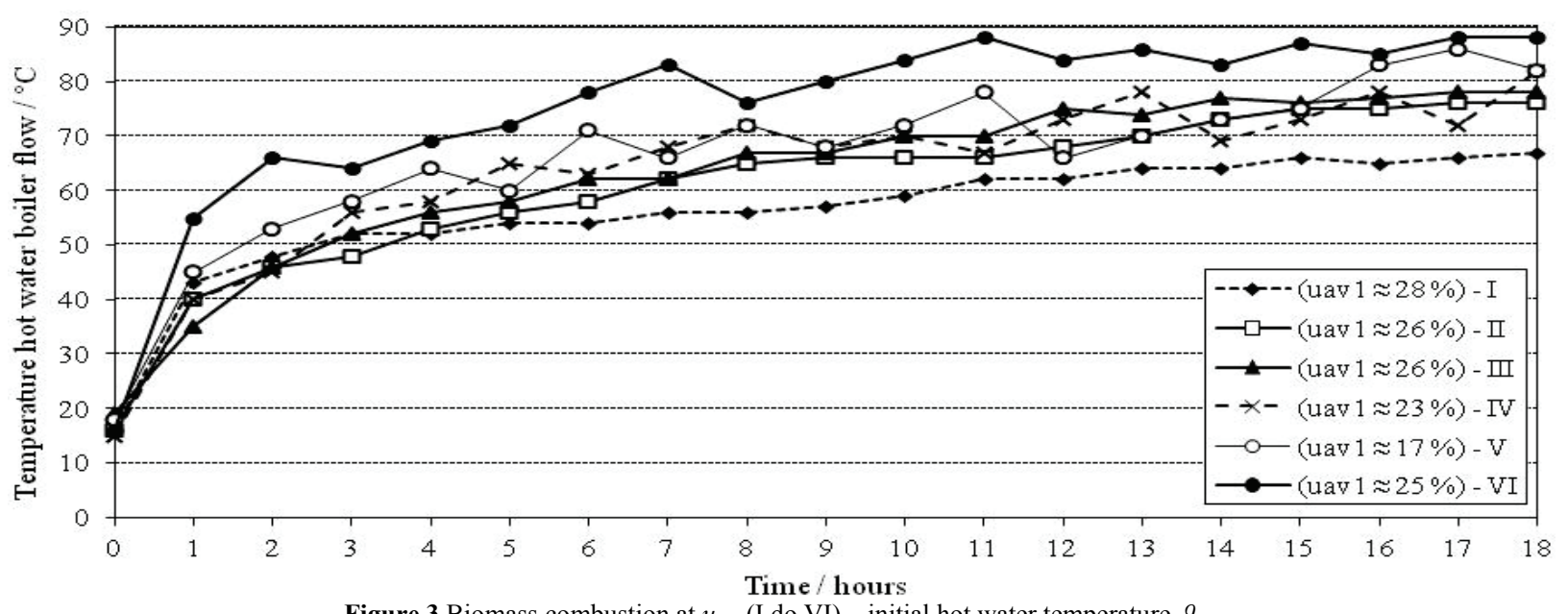

Figure 3 Biomass combustion at $u_{\mathrm{av} 1}$ (I do VI) - initial hot water temperature $\vartheta_{\mathrm{w} 1}$



Figure 4 Biomass combustion at $u_{\mathrm{av} 2}$ (I do VI) - initial hot water temperature $\vartheta_{\mathrm{w} 1}$

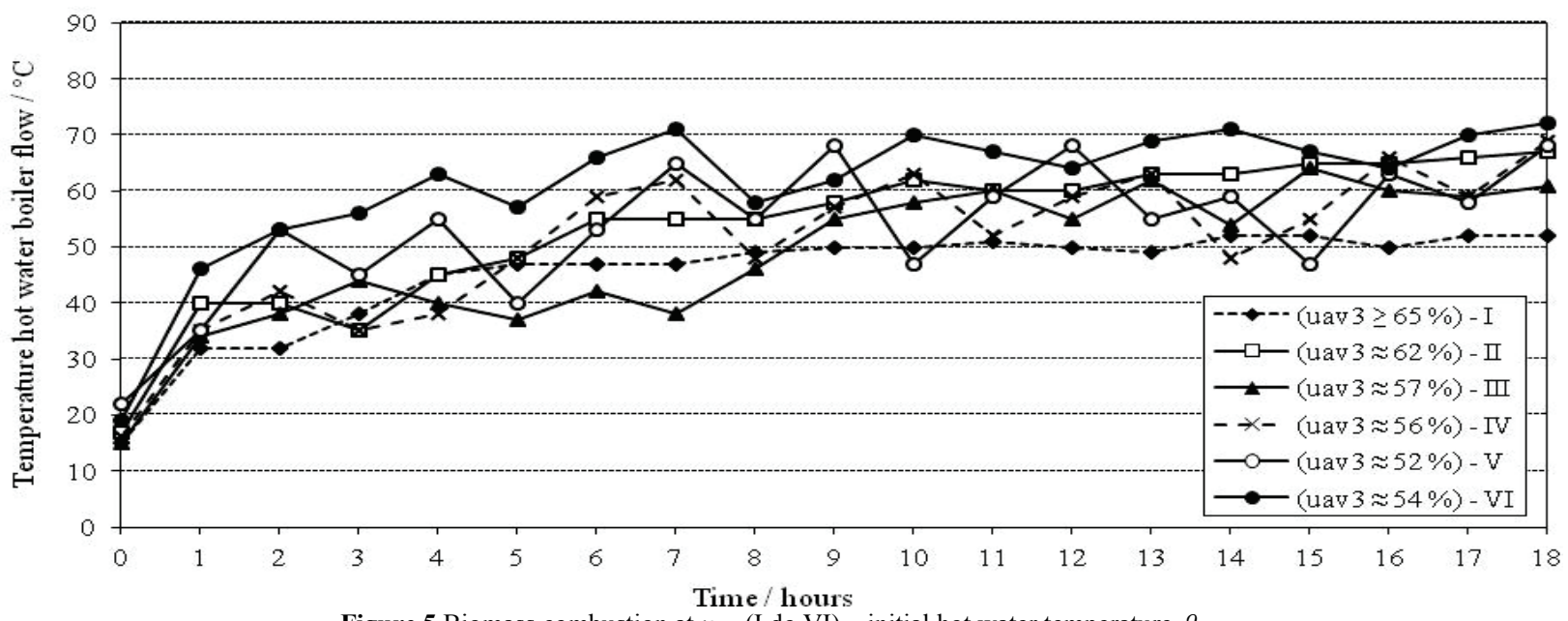

Figure 5 Biomass combustion at $u_{\mathrm{av} 3}\left(\mathrm{I}\right.$ do VI) - initial hot water temperature $\vartheta_{\mathrm{w} 1}$

In the same trial intervals of biomass mixture combustion of groups I to VI for three different average moisture levels $\left(u_{\mathrm{av} 1}<u_{\mathrm{av} 2}<u_{\mathrm{av} 3}\right)$, the temperature of purified flue gases $\vartheta_{\mathrm{fg}}$ was measured and shown in diagrams in Figs. 6, 7 and 8.

Within subsequent intervals each 2 hours during each cycle of individual biomass mixtures I to VI and various moisture levels $\left(u_{\mathrm{av} 1}<u_{\mathrm{av} 2}<u_{\mathrm{av} 3}\right)$, the change in the height of the column $\Delta h_{\mathrm{sx}}$ of biomass in the container $V_{\mathrm{s}}$ was measured. With previously determined value of the biomass mixture density in absolutely dry state $\rho_{\mathrm{bmo}(\mathrm{I}, \mathrm{VI})}$, known container dimensions and using Eqs. (5), (6) and (7), the required amount of biomass was calculated. Quantified values are shown in diagrams in Fig. 9. 


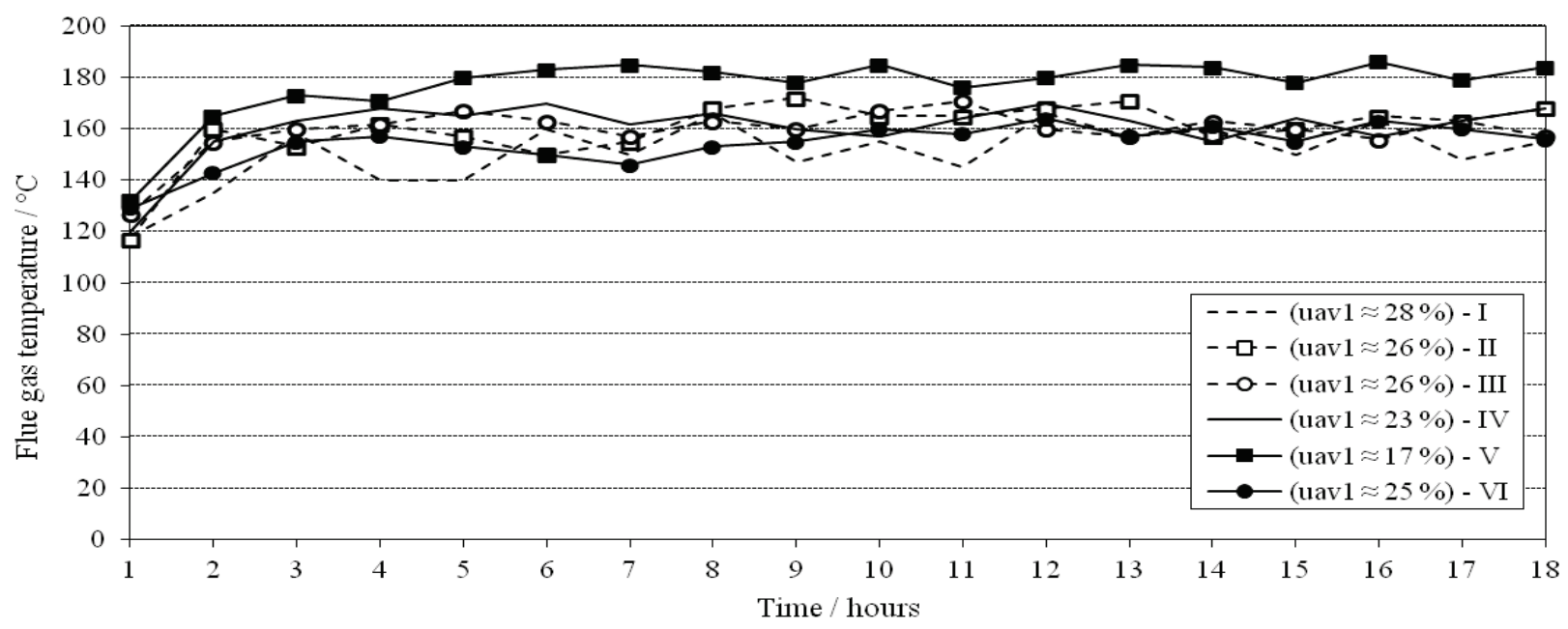

Figure 6 Biomass combustion at $u_{\text {av1 }}$ (I do VI) - temperature of flue gases $\vartheta_{\mathrm{fg}}$

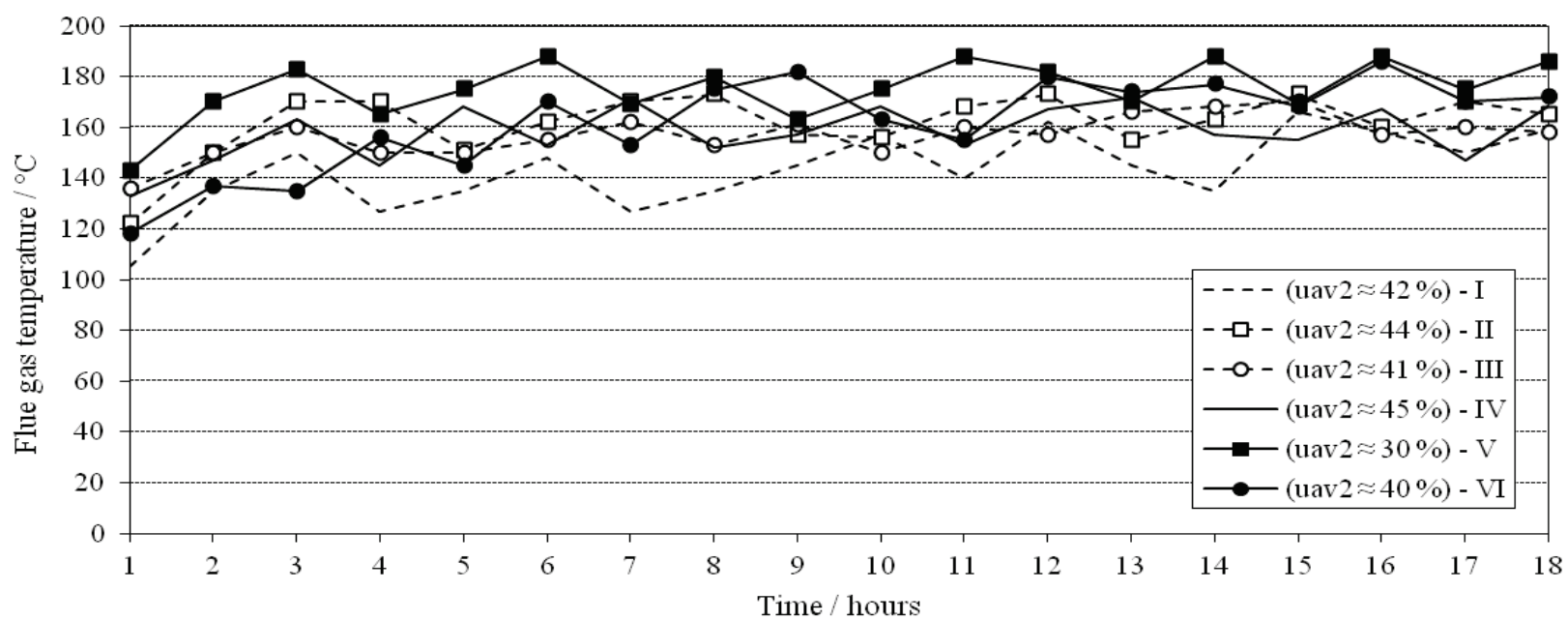

Figure 7 Biomass combustion at $u_{\mathrm{av} 2}$ (I do VI) - temperature of flue gases $\vartheta_{\mathrm{fg}}$

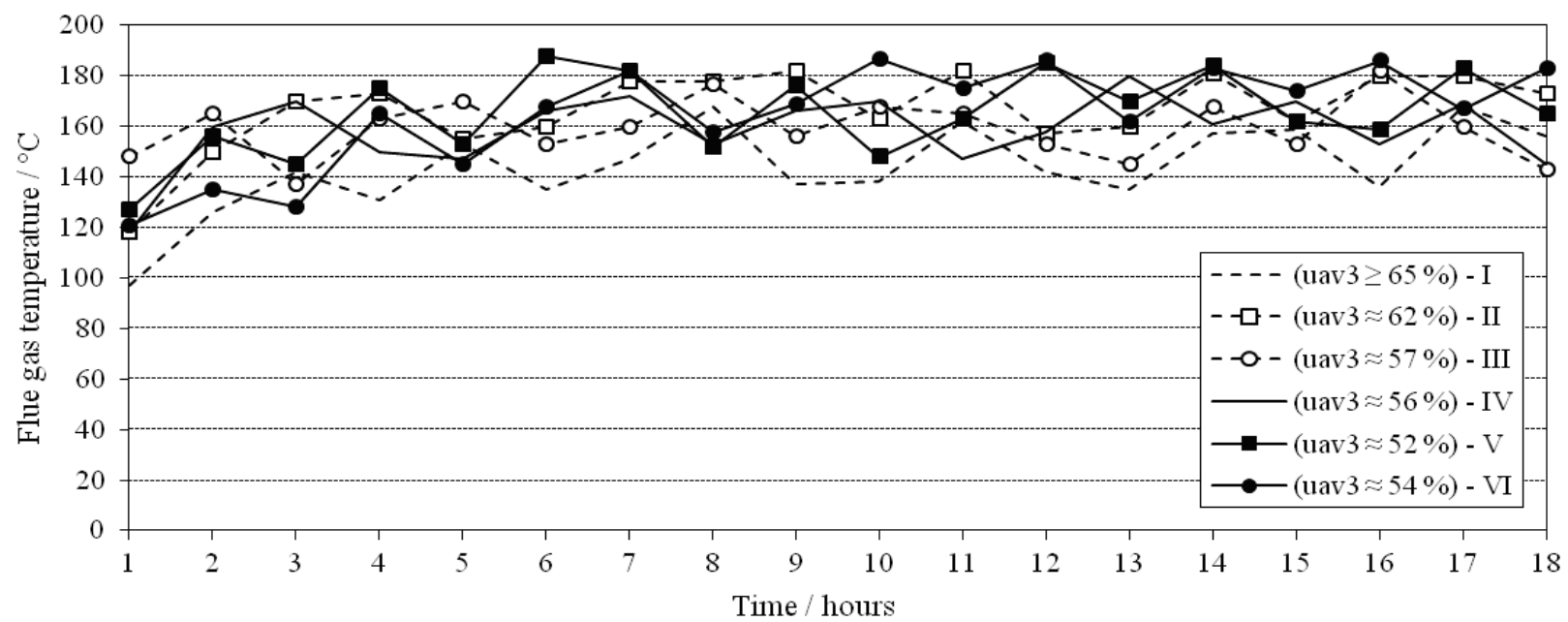

Figure 8 Biomass combustion at $u_{\mathrm{av} 3}$ (I do VI) - temperature of flue gases $\vartheta_{\mathrm{fg}}$

After each combustion cycle of an individual group and average moisture of biomass mixture, a check-up and cleaning of the pyrolytic chamber, furnace and the heat exchange surfaces of the boiler were carried out. Depending on the used group of biomass mixture and its average moisture, a larger or smaller amount of slag and incombustible solid matters were identified, i.e. a negligible amount of ashes, which affects the combustion efficiency and heat exchange of the boiler's heating surfaces $[6,8]$. An extremely rapid development of larger amounts of solid deposits and incombustible matters in the pyrolytic chamber and boiler furnace during biomass combustion of the biomass group I for all of its average moisture levels, Fig. 10, was identified.

During the combustion of biomass mixture of various wood types and wood chips to sawdust ratios (II, III, IV, $\mathrm{V})$ and of various average moisture levels, small amounts 
of particles of powder material and ashes develop, as shown in Fig. 11.



Figure 9 Biomass consumption (I to VI) $u_{\mathrm{av} 1}<u_{\mathrm{av} 2}<u_{\mathrm{av} 3}$

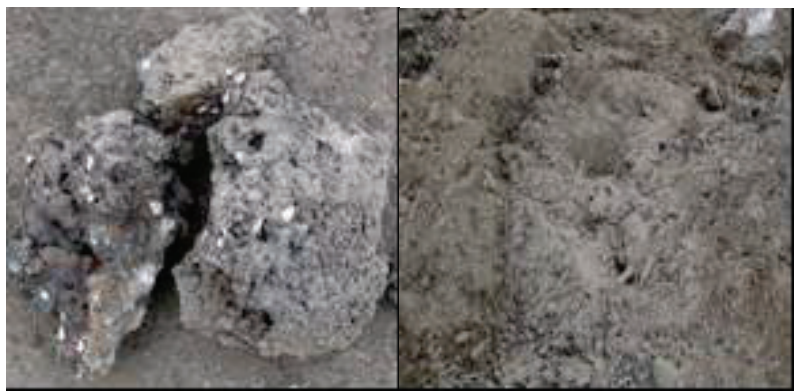

Figure 10 Biomass I - solid deposits and incombustible matters

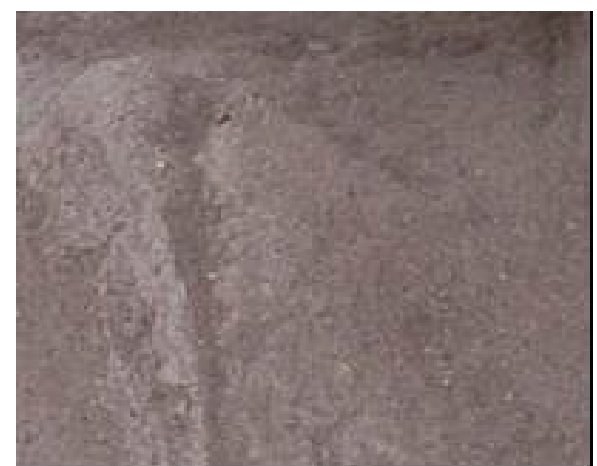

Figure 11 Biomass (II, III, IV, V) - combustion residues

The combustion of the mixture of beech and oak wood chips and sawdust at a constant ratio and different average moisture (group VI) a significantly lower or negligible amount of tiny particles of ashes develops, which has no significant influence on the efficiency of the thermal power plant drive.

\section{Analysis of results}

The rate of achieving and maintaining a stable initial work temperature of hot water within a district heating system at peak load is significantly affected by biomass quality, its combustion and the efficiency of transforming it into final thermal energy. Achieving and maintaining the initial temperature of hot water ranging between $80^{\circ} \mathrm{C}$ and $90^{\circ} \mathrm{C}$ is allowed for by the combustion of the mixture of beech and oak wood chips and sawdust at a constant ratio (group VI) with the average moisture amounting to approximately $u_{\text {av1 }}=25 \%$. By increasing the average moisture of the biomass group VI to $u_{\mathrm{av} 2}=40 \%$, the initial water temperature decreases by around $8{ }^{\circ} \mathrm{C}$ to 10 ${ }^{\circ} \mathrm{C}$, while at $u_{\text {av } 3}=54 \%$ by around $15{ }^{\circ} \mathrm{C}$ to $20{ }^{\circ} \mathrm{C}$ of the required value under approximately equal conditions and duration of each combustion cycle. The temperature of flue gases is approximately constant at average biomass moisture (group VI) $u_{\text {av1 }}$ and amounts to approximately $180{ }^{\circ} \mathrm{C}$, while with the increase in average moisture $\left(u_{\text {av2 }}\right.$ and $\left.u_{\mathrm{av} 3}\right)$, its values oscillate $140{ }^{\circ} \mathrm{C}$ and $180{ }^{\circ} \mathrm{C}$ during the combustion cycle interval.

Using the group I biomass mixture, the maximum temperature of initial water amounting to $50{ }^{\circ} \mathrm{C}$ to $65{ }^{\circ} \mathrm{C}$ was achieved at the end of trial combustion cycles, which jeopardizes and prevents achieving and stable maintaining of the air temperature in the plant vegetation zone in a greenhouse, especially with biomass of higher average moisture. Larger amounts of solid deposits and solid matters develop in the pyrolytic chamber and the boiler furnace. The oscillation of flue gas temperature ranging between $135{ }^{\circ} \mathrm{C}$ and $165{ }^{\circ} \mathrm{C}$ is expressed, with sudden changes in the case of higher average moisture $u_{\text {av3 }}$ of the group I biomass mixture.

In the case of combustion of the biomass mixture of the groups II, III, IV and $\mathrm{V}$ with the average moisture $u_{\mathrm{av}}$ $=17 \div 26 \%$, the maximum temperature of initial water ranging between $70{ }^{\circ} \mathrm{C}$ and $80{ }^{\circ} \mathrm{C}$ is achieved after $2 / 3$, and the temperature of initial water above $60{ }^{\circ} \mathrm{C}$, which is required for district heating purposes, after the $1 / 3$ of the duration of each trial cycle. By increasing the average moisture to $u_{\text {av2 }}$ and $u_{\text {av } 3}$, and by means of combustion of the aforementioned biomass groups, the initial hot water temperature is lower by around $5{ }^{\circ} \mathrm{C}$ to $8{ }^{\circ} \mathrm{C}$, which directly affects the reduction of air temperature in the vegetation zone below a technologically recommendable value $\left(\vartheta_{\mathrm{gh}}=19^{\circ} \mathrm{C}\right)$ mostly in the night work mode. The temperature of flue gases averagely ranged between 150 ${ }^{\circ} \mathrm{C}$ and $180{ }^{\circ} \mathrm{C}$ with more expressed value oscillations as the average biomass moisture of groups I to VI increased during each combustion cycle.

In the case of the highest average moisture $u_{\mathrm{av} 3}$ of the biomass groups I to $\mathrm{V}$ significant initial water temperature oscillations and heating instabilities of the district heating system were identified during time intervals of each trial combustion cycle. During the combustion of biomass with the lowest amount of combustible matters (group I) the lowest initial water temperature amounting to $50{ }^{\circ} \mathrm{C}$ to $65{ }^{\circ} \mathrm{C}$ is achieved, with a small oscillation of its value during each combustion cycle.

For achieving a suitable thermal effect under approximately equal microclimate and technological conditions, the lowest consumption is the one regarding the mixture of beech and oak wood chips and sawdust at a constant ratio and different average moisture (group VI), Fig. 9. Around 3,3 to 4 times lower is the consumption of the group VI biomass in comparison to the group I biomass of average moisture $u_{\mathrm{av} 1}, u_{\mathrm{av} 2}$ and $u_{\mathrm{av} 3}$. With the increase of average moisture, the group I biomass consumption significantly increases (1,3 to 2 times). As there is a larger amount of incombustible matters that form solid deposits during the combustion process, the efficiency of the thermal power plant reduces at approximately equal thermal effect. The consumption of 
biomass of groups I to VI with average moisture $u_{\mathrm{av} 2}$ is higher by around $26 \%$, while it amounts to around $70 \%$ to $110 \%$ for the ones with average moisture $u_{\text {av3 }}$ in comparison with biomass of average moisture $u_{\mathrm{av} 1}$.

\section{Conclusion}

A low time constant and thermophysical characteristic of greenhouses increase the sensitivity of the internal air temperature in the plant vegetation zone, especially in the night work mode at low external air temperatures. A hot water plant of the heat to power ratio amounting to $Q=600 \mathrm{~kW}$ was used for examining the temperature of the heating medium and flue gases for the purpose of testing different biomass mixtures classified into six groups I to VI for three cases of average initial moisture $u_{\text {av1 } 1}, u_{\text {av2 }}$ and $u_{\text {av } 3}$, in comparison to the achieved thermal effect of a low-accumulation object at a low external air temperature, mostly in the night work mode. Quantified values showed the consumption of all groups and average moisture levels of biomass. By analysing the tested thermotechnical parameters during the combustion of each biomass group, a direct influence of its quality and average moisture on the efficiency of the district heating system of a low-accumulation object was shown. The combustion of the mixture of wood chips and sawdust in a constant ratio and with different average moisture (VI) resulted in sustainable and stable parameters of the district heating system with the lowest consumption of biomass and negligible amount of combustion residues. A direct application of research results contributes to a correct identification of the type, composition and average moisture of biomass, as well to the efficiency of the whole thermal power system.

\section{References}

[1] Ergul, E.; Ayrilmis, N. Effect of outdoor storage conditions of wood chip pile on the technological properties of woodbased panel. // Biomass and Bioenergy. 61, (2014), pp. 6672. DOI: 10.1016/j.biombioe.2013.11.025

[2] Čikić, A.; Kondić, Ž. Research of the waste biomass technical and economic valve as one of the technological and energy development criteria wood processing plants. // Tehnicki vjesnik-Technical Gazette. 17, 1(2010), pp. 53-59.

[3] Demirbas, A. Combustion characteristics of different biomass fuels. // Progress in Energy and Combustion Science. 30, 2(2004), pp. 219-230. DOl: 10.1016/j.pecs.2003.10.004

[4] Demirbas, A. Potential applications of renewable energy sources, biomass combustion problems in boiler power systems and combustion related environmental issues. // Progress in Energy and Combustion Science. 31, 2(2005), pp. 171-192. DOI: 10.1016/j.pecs.2005.02.002

[5] Čikić, A.; Pintarić, A.; Samardžić, I. The influence of biomass quality on the purification of flue gases and multicyclone assembly material. // Metallurgy. 52, 1(2013), pp. 111-114.

[6] Riaza, J.; Gil, M. V.; Alvarez, L.; Pevida, C.; Pis, J. J.; Rubiera, F. Oxy-fuel combustion of coal and biomass blends. // Energy. 41, 1(2012), pp. 429-436. DOl: 10.1016/j.energy.2012.02.057

[7] Chau, J.; Sowlati, T.; Sokhansanj, S.; Preto, F.; Melin, S.; $\mathrm{Bi}, \mathrm{X}$. Economic sensitivity of wood biomass utilization for greenhouse heating application. // Applied Energy. 86, 5(2009), pp. 616-621. DOI: 10.1016/j.apenergy.2008.11.005

[8] Ozgen, E.; Cemuschi, S.; Giugliano, M. Experimental evaluation of particle emissions from wood combustion in closed fireplace. // Biomass and Bioenergy. 50, (2013), pp. 65-74. DOI: 10.1016/j.biombioe.2013.01.015

\author{
Authors' addresses \\ Ante Čikić, Ph.D. Associate Prof. \\ Technical College in Bjelovar \\ Trg Eugena Kvaternika 4, \\ 43000 Bjelovar, Croatia \\ E-mail: acikic@vtsbj.hr
}

Vinko Višnjić, Ph.D. Associate Prof

University North,

University Centre of Varaždin

104. brigade 4

42000 Varaždin, Croatia

Marko Dunder, Ph.D. Full Prof.

Faculty of Philosophy,

University of Rijeka,

Department of Polytechnic,

Omladinska 14,

51000 Rijeka, Croatia 